- the wrong turn of blending ingredients and semi-finished products,

- irrational ways of blend stabilization before filtering,

- insufficient maturing of the blend,

- the use of raw filter paper for blend filtration etc.

Longer expiration dates of tinctures can be obtained by increasing the resistance due to multi-stage processing: on the processing stages of each semi-finished product and the following processing of the finished blend.

\title{
References:
}

1. Sergeeva, I.Y. Classification of components of opacities of drinks from plant materials. Technique and technology of food production. 2016. T. 42. No. 3. Pp. 70-76.

2. Polyakova I.V. Methods for stabilizing alcoholic beverages. [Text] I.V. Polyakova, A.B. Danilovtseva, V.V. Zhirova, A.L. Panasyuk // Sat. tr IX Int. scientific and practical. conf. «Strategy for the development of the food industry». Moscow: MGUTU, 2003. Pp. 39-41.

\section{METHOD TO IMPROVE OF RELIABILITY AND SERVICE LIFE GROWTH FOR OPEN GEAR DRIVE}

\section{Anton Riazantsev ${ }^{1}$}

DOI: https://doi.org/10.30525/978-9934-588-11-2_13

Gear drive takes the leading place in mechanical systems (machines and mechanisms) and the industrial safety and output quality depends on its current technical condition. They are operated in conditions of impulsive-cyclic subgrade loads, which cause high requirements for the loadbearing of gear drive. Reduction of loadbearing is determined by such reasons as: weakening of the tooth at its base, fatigue spalling of contact point and wear of tooth profile.

For increase of reliability of gear and transmission it is of current interest the following: development of scientifically grounded and proved evaluation criteria for limit state of gear drive; development of methodology for operational evaluation of wear rate of teeth working area; improvement of technology of their case-hardening.

Researches concerning determination of common patterns of abrasive wear are the most interesting. The range of works in this direction is based on the usage of theory of similarity. Researches based on the study of abrasive grain mechanic in the zone of teeth contact (Gavrilenko V.A., Ermichev V.A., Kashcheev V.N.) are of great interest. Data of the work is further developed by G.Ya. Yampol'skiy, A.P. Natarov, I.V. Kragel'skiy [1;2; 3; 4].

Exploitation experience and experimental research show that service life of rim is determined by economic aspect, not physical capacity. At certain value of rim wear, service life of gear wheel reduces insomuch that its further exploitation does not

\footnotetext{
${ }^{1}$ Kryvyi Rih National University, Ukraine
} 
make sense. The Figure 1 shows experimental dependence of the wear rate of MB$7000 \times 2300$ mills gear wheel in conditions of Inguletsk mining-and-processing integrated works on the averaged value of wear of the rim teeth.

During the initial period of exploitation of MB-7000x2300 mills, longevity of drive gear was 3-3.5 years. After the wear of rim teeth on the value $\Delta \mathrm{S}_{2}=6.6 \mathrm{~mm}$, service life of drive gear reduced to 6-8 months.

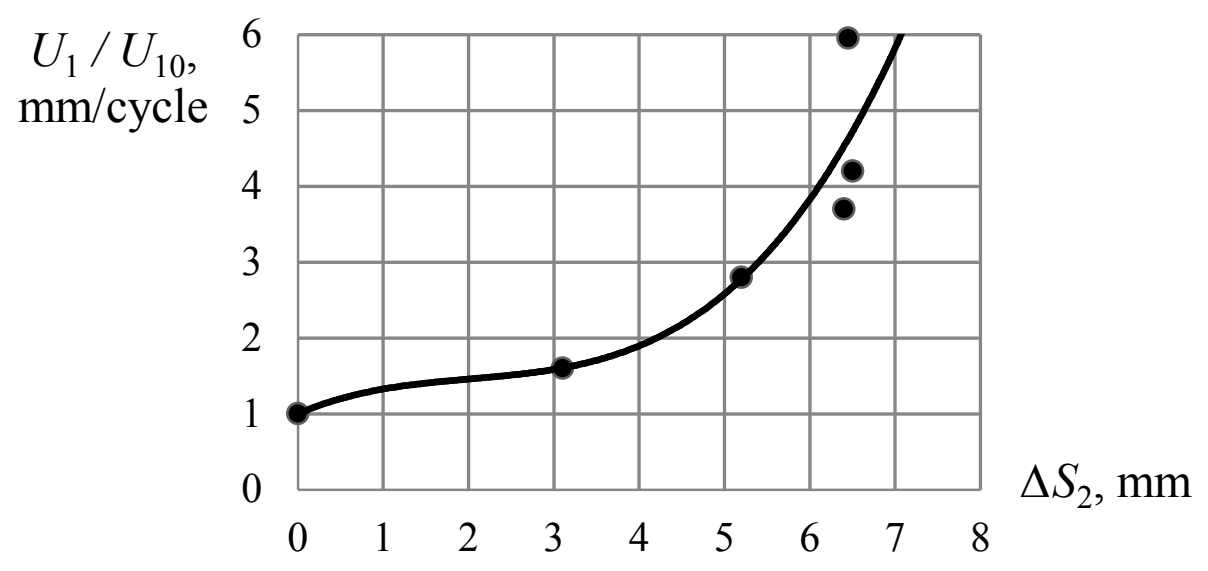

Figure 1. Dependence of wear rate of MB-7000x2300 mills gear teeth on the wear value of rim teeth, $U_{10}$ - wear rate at initial time (at $\Delta S_{2} \approx 0$ )

For heavy-duty elements of friction pairs, to which toothed wheel gearing of exposed drives of mills refers, the wear rate, depending on the conditions of abrasive action $A$, physic-mechanical properties of materials $M_{1(2)}$, geometrical and linkage parameters of integrations $K$, may be presented as following.

$$
U_{1(2)}=6,8 \frac{A K}{M_{1(2)}}
$$

where $U_{1(2)}$ - wear per one loading; $A=q_{a}^{2 / 3} A^{0.5} \sigma^{2.5} ;\left(q_{a}-\right.$ concentration of abrasive impurities in the lubricant or air,\%; R - their midradius, $\mathrm{mm}$; $\sigma$ - tensile strength, $\mathrm{MPa}) ; M_{1(2)}=\delta_{1(2)}^{t} H B_{1(2)}^{1,5} H B_{2(1)}\left(\delta_{1(2)}-\right.$ characteristic of surface coating plasticity elongation at failure; $\mathrm{t}-$ contact friction fatigue coefficient; $K=\sqrt{\rho^{*}} \cdot \frac{V_{1}-V_{2}}{V_{1}+V_{2}}$; $\rho^{*}=\frac{\rho_{1} \cdot \rho_{2}}{\rho_{1}+\rho_{2}}$ - relative radius of curvature of joint surfaces, mm; $V_{1}, V_{2}-$ slip velocities of joint surfaces, $\mathrm{m} / \mathrm{s}$ ).

The data processing shows that analytical expressions quite correctly describe abrasive wear of teeth of exposed drive of mills. Besides, for drives that are in close conditions, quantitative agreement of results is also satisfying.

During evaluation of influence of mechanical-and-physical properties of material of gear wheels, as it was mentioned before, in accordance with (1) the value, characterizing mechanical-and-physical properties of material of gear wheels 
$M=\delta^{t} H B_{1(2)}^{1,5} H B_{2(1)}$, influences the velocity of abrasive wear. Value $\sigma$ is the combined variable of parameter characterizing abrasive action of the medium. Therefore, $\sigma$ is the function of hardness of active surfaces of teeth. That is why, considering the influence of mechanical-and-physical properties of materials, let us note that the wear rate:

$$
U_{1(2)} \approx \frac{\sigma^{2,5}}{\delta^{t} H B_{1(2)}^{1,5} H B_{2(1)}}
$$

Increase of hardness of active surfaces of teeth causes the reduction of $\sigma$. As one may see from (2) the increase of teeth hardness of one of the wheels leads to the reduction of wear rate as the teeth of the other wheel of gear set.

Increase of hardness of active teeth surfaces of open gear wheels, besides it promotes the reduction of accompanying species of wear, increase of their contact hardness.

Experimental research of influence of hardness of active surfaces of teeth on their longevity was fulfilled in conditions of Pridneprovskiy hydroelectric power plant on Sh-50 mills. Gear teeth were exposed to case-hardening by high-frequency currents. In result of imperfection of production method, surface hardness of various teeth was different. During operation of gear wheel, wear rate of teeth was measured, depending on the hardness of their active surfaces. Experimental results are shown in the figure 2 .

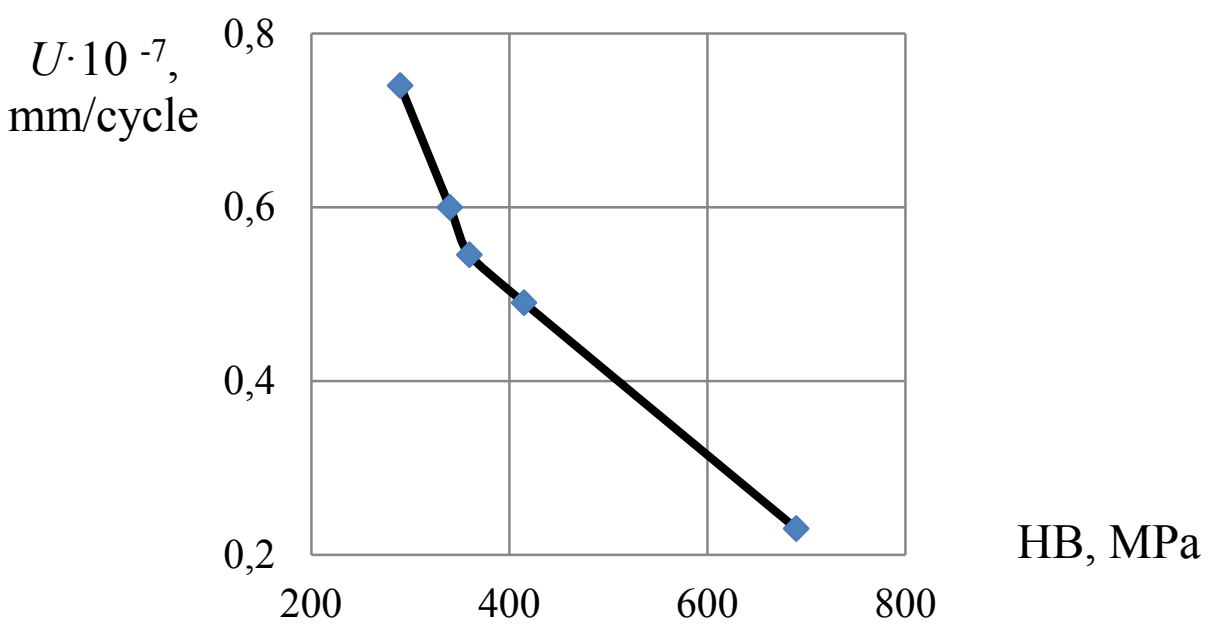

Figure 2. dependence of the wear rate of gear teeth on the hardness of their active surfaces (Sh-50mill, Pridneprovskiy hydroelectric power plant)

Therefore, increase of durability and longevity of coarse-grained tooth gear operation is of high priority for all machine builders.

The above mentioned necessitates the researches of existing technologies for solution of task of performance incoordination, increase of service life, wearresistance of working area of teeth of coarse-grained gear wheels. Upcoming trend here is work-hardening heat treatment of working area by concentrated energy flow 
[5, p. 124]. The structures of hardening type, which are formed during flash heat and cooling, have high hardness, wear-resistance, crack strength.

Common use of known ways of work-hardening by concentrated energy flow (laser, cathode ray, cathode- ionic, etc) is restricted by high cost and complexity of equipment, its insufficient reliability and capacity, necessity of vacuum usage, special places with particular requirements, demand for qualified operation, high maintenance charges. In these conditions surface tempering by plasma arc is reasonable in parameters of generality, availability, environmental friendliness and economical efficiency for prolongation of service life of fast wearing parts [5]. Not changing surface roughness parameters, such heat treatment easily fits into production process of prepare and repair of parts, being a final stage, low-cost, rather productional and allows to increase their service durability effectively.

The aim of plasma tempering is the increase of service life of machine parts due to hardening of their surface coating (several $\mathrm{mm}$ in thickness) by thermal treatment of plasma arc at permanent common chemistry of material and retention of initial properties of material in the inner layers.

Hardening in result of high-speed local heating by plasma arc of surface coating to high temperatures (higher than $\mathrm{Ac}_{3}$ ) and its rapid cooling with higher critical speed as a result of heat removing into deep layers (inner) of material. Being formed structures during flash heat and cooling of tempering type have high hardness, wear resistance and crack strength. Effect from plasma tempering is determined by increase of part service characteristics due to change of physical and mechanical characteristics of surface coating, because of formation of specific structure and phase metal content and also formation of compressive residual stresses on the surface. Structural changes in common correspond to the occurring ones during volume tempering, but the velocities of heating and cooling cause changes of the relations between structural components, their morphology changes as a result of increased defectiveness of crystalline structure (increase of dislocation content, crushing of blocks and stress raisers in crystal latitude) [5]. The structure of hardened layer with high hardness and dispersability affects the changes of exploitation parameters of hardened materials wear-resistance, mechanical properties (durability, plasticity, crack resistance and enduring quality), heat- and corrosion resistance.

\section{References:}

1. Karagel'skiy, I. V., Dobychin, M. N., Kombalov, V. S. (1977). Osnovy raschetov na trenie i iznos [Calculation basis for friction and wear]. Moscow : Mashinostroenie. (in Russian)

2. Natarov, A. P. (1978). Issledovanie vliyaniya geometricheskikh parametrov zubchatykh peredach, rabotayushchikh v sredakh s nalichiem abraziva na ikh dolgovechnost': avtoreferat dis. na soiskanie nauch. stepeni kand. tekhn. nauk [Analysis of geometrical effects of gear wheels being operated in mediums with abrasive on their longevity]. Khar'kov. (in Russian)

3. Yampol'skiy, G. Ya., Kragel'skiy, I. V. (1973). Issledovanie abrazivnogo iznosa elementov par treniya kacheniya [Investigation of abrasive wear of tribological components of rolling]. Moscow : Nauka. (in Russian)

4. Yampol'skiy, G. Ya., Natarov, A. P. (1975). Raschet abrazivnogo iznosa zub'ev zubchatykh peredach [Calculation of abrasive wear of gear wheels]. Bryansk. (in Russian) 
5. Nechaev, V. P., Ryazantsev, A. A. (2012). Modifikatsiya svoystv poverhnostnyih sloev tyazhelonagruzhennyih detaley gornyih mashin posredstvom plazmennogo uprochneniya [Modification of properties of surface coatings of heavy-loaded machine parts by means of plasma hardening]. Visnik Krivoriz'kogo natsional'nogo universitetu. Zbirnik naukovikh prats' - Journal of Kryvyi Rih National University, Vol. 32 123-127. (in Russian)

\section{THE DOMINANT FACTORS DURING WATER TREATMENT IN THE BEVERAGE PRODUCTION}

\section{Iryna Samchenko ${ }^{1}$ Svitlana Oliynyk ${ }^{2}$}

DOI: https://doi.org/10.30525/978-9934-588-11-2_14

Ensuring high quality and durability of products in alcoholic beverage production is achieved using the main ingredients: ethyl rectified spirit of the varieties of «Wheat tear» or «Luxury» and prepared water with high organoleptic indicators, balanced microcomponents cationic-anionic composition [1, p. 325].

At each stage of the technological process of production of alcoholic beverages, including water treatment, it is necessary to determine the dominant factors that will largely determine the quality of treated water [2, p. 7].

So the dominant factors for individual air-conditioning units of water during:

- mechanical purification are mechanical, structural, physico-chemical characteristics and chemical resistance filter media, the subtlety and flow velocity, the specific volume of the filtrate before reaching the limit values for opacity and tabarlet, timeliness of regeneration and the like;

- deironing and demangeat is structural and physico-chemical characteristics of filter materials, the filtration rate and the ability to modify a specific volume of the filtrate before reaching the limit values for iron and manganese content, determination of the possibility and efficiency of regeneration and the like;

- sorption purification are mechanical, structural, physicochemical and sorption characteristics of the sorption material, the limit values for sorbolene substances, the effectiveness of one or more sorbents to various directed action, the specific filtrate volume to achieve the limit values for permanganate Okinawans, the filtration rate, the possibility of regeneration, the impact of regenerating agents, etc.);

- mitigation is the physico-chemical characteristics of ion exchange material, the specific volume of softened water, filtration rate and regeneration efficiency, the minimum hardness value of treated water in the filtration cycle, the possibility of contamination of the ion exchanger with organic substances and the like;

\footnotetext{
${ }^{1}$ National University of Food Technologies, Ukraine

${ }^{2}$ National University of Food Technologies, Ukraine
} 